\title{
A Record of Syn-Tectonic Sedimentation Revealed by Perched Alluvial Fan Deposits in Valles Marineris, Mars
}

\section{Supporting Information}

Joel M. Davis ${ }^{1 *}$, Peter M. Grindrod ${ }^{1}$, Steven G. Banham² ${ }^{2}$ Nicholas H. Warner ${ }^{3}$, Susan J. Conway ${ }^{4}$, Sarah J. Boazman ${ }^{1}$, and Sanjeev Gupta ${ }^{3}$

${ }^{1}$ Department of Earth Sciences, Natural History Museum, London, SW7 5HD, UK

${ }^{2}$ Department of Earth Science and Engineering, Imperial College, London, SW7 2BU, UK

${ }^{3}$ Department of Geological Sciences, State University of New York at Geneseo, Geneseo, NY, 14454, USA

${ }^{4}$ CNRS, UMR 6112 Laboratoire de Planétologie et Géodynamique, Université de Nantes, 44322 Nantes, France

*Corresponding author: joel.davis@nhm.ac.uk

This file contains the detailed methods relating to the production of the stereo CTX mosaic as well as the morphometrics for the alluvial fans in Coprates Chasma and Juventae Chasma in Valles Marineris (Table S1). Also shown are HiRISE (Figure S2, S5) and CRISM (Figure S4) observations of Coprates Chasma fans. Figure S3 shows the fan apices and catchment areas for Coprates and Juventae Chasma fans. Figure S6 shows the topographic setting of the Juventae Chasma fans. CTX and HiRISE observations of the Juventae Chasma fans are shown in Figure S7. Figure S8 shows a conceptional model of the evolution of the Coprates Chasma canyon. Finally, Table S2 provides the image identification numbers used in all figures. 


\section{Production of stereo southeast Coprates Chasma CTX DEM mosaic}

Digital elevation models (DEMs) were produced from CTX stereo images using the USGS Integrated Software for Imagers and Spectrometers (ISIS) software and the BAE photogrammetric package SOCET SET according to the method of Kirk et al. (2008). We selected 10 CTX image pairs to maximise coverage of the canyon. Tie points were automatically populated in SOCET SET between each image pair. We ran a series of bundle adjustments, removing erroneous tie points until the remaining points had an RMS pixel matching error of $\leq$ 0.6 pixels. The resultant DEM was then tied to Mars Orbiter Laser Altimeter (MOLA; Zuber et al., 1992) topography and exported with a horizontal post spacing of $20 \mathrm{~m} /$ pixel. We then exported orthorectified images from SOCET SET at a resolution of $6 \mathrm{~m} /$ pixel. The orthorectified images and DEMs were then mosaicked in ArcGIS. Finally, the orthorectified image mosaic was blended in Adobe Photoshop to remove seamlines using the Avenza Geographic Imager extension, which retains geospatial information in the blended product. We also produced an additional CTX DEM of alluvial fans in Juventae Chasma, where coverage was available.

\section{Data availability}

The standard remote sensing data products used here are available from the NASA Planetary Data System (https://pds.jpl.nasa.gov/). The CTX ortho images and digital elevation models are availabe for download from Figshare (https://doi.org/10.6084/m9.figshare.c.5306507.v1). 


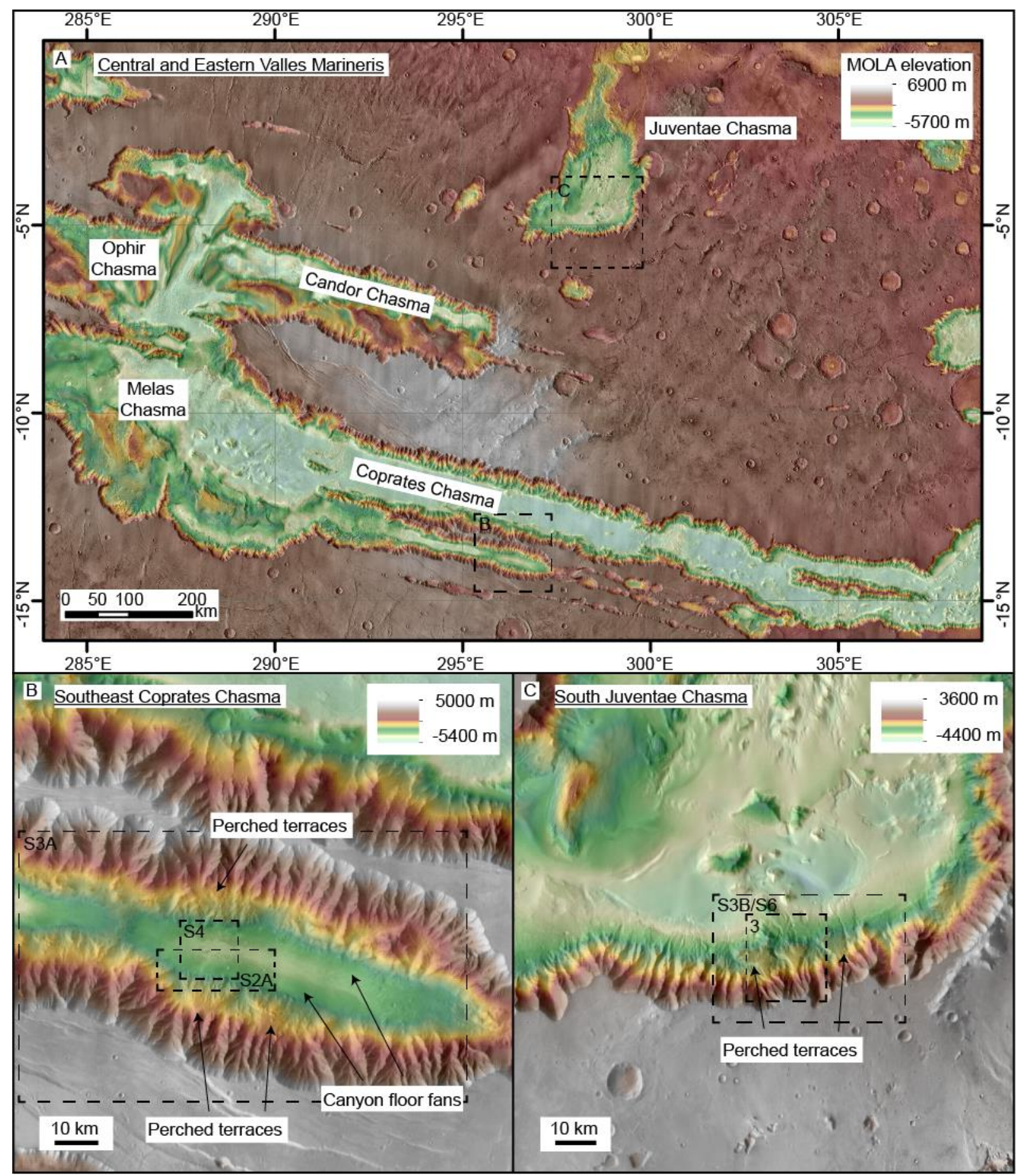

Figure S1: (A) Mars Orbiter Laser Altimeter (MOLA; Zuber et al., 1992) topographic map overlaid on THEMIS-IR day basmap showing the central and eastern Valles Marineris canyons. (B) MOLA topographic map overlaid on THEMIS-IR day basmap showing part of southeast Coprates Chasma, where the perched terraces and canyon floor fans are found. (C) MOLA topographic map overlaid on THEMIS-IR day basmap showing the southern wall of Juventae Chasma where the perched terraces are found. 


\begin{tabular}{|c|c|c|c|c|c|c|c|c|}
\hline Study site & Gen. & Fan & $\begin{array}{l}\text { Lat/Lon } \\
\text { of apex }{ }^{\dagger}\end{array}$ & $\begin{array}{c}\text { Apex } \\
\text { elevation }\end{array}$ & $\begin{array}{c}\text { Fan } \\
\text { catchment } \\
\left(\mathrm{km}^{2}\right)\end{array}$ & $\begin{array}{c}\text { Fan } \\
\text { area } \\
\left(\mathbf{k m}^{2}\right) \\
\end{array}$ & $\begin{array}{l}\text { Fan slope } \\
\text { (degrees) }\end{array}$ & $\begin{array}{l}\text { Cathment } \\
\text { relief }(\mathrm{km})\end{array}$ \\
\hline SE Copr.* & $\mathrm{C} 1$ & C1_A & $-13.95^{\circ}, 295.55^{\circ}$ & -74.88 & - & 8.20 & 9.31 & - \\
\hline SE Copr. & $\mathrm{C} 1$ & $\mathrm{C} 1 \_\mathrm{B}$ & $-14.12^{\circ}, 296.18^{\circ}$ & -422 & - & 5.18 & 8.47 & - \\
\hline SE Copr. & $\mathrm{C} 1$ & $\mathrm{C} 1 \_\mathrm{C}$ & $-14.15^{\circ}, 296.12^{\circ}$ & -273.45 & - & 7.01 & 10.71 & - \\
\hline SE Copr. & $\mathrm{C} 1$ & C1_D & $-14.23^{\circ}, 296.38^{\circ}$ & -124.1 & - & 7.70 & 8.82 & - \\
\hline SE Copr. & $\mathrm{C} 1$ & C1_E & $-14.24^{\circ}, 296.33^{\circ}$ & -154.46 & - & 7.72 & 7.33 & - \\
\hline SE Copr. & $\mathrm{C} 1$ & C1_F & $-13.63^{\circ}, 296.18^{\circ}$ & -467.93 & - & 3.55 & 6.45 & - \\
\hline SE Copr. & $\mathrm{C} 2$ & C2_A & $-13.75^{\circ}, 295.98^{\circ}$ & -2510.46 & 65.41 & 24.25 & 5.78 & 6.57 \\
\hline SE Copr. & $\mathrm{C} 2$ & C2_B & $-13.98^{\circ}, 296.13^{\circ}$ & -2668.10 & 290.91 & 9.65 & 11.34 & 5.07 \\
\hline SE Copr. & $\mathrm{C} 2$ & $\mathrm{C} 2 \_\mathrm{C}$ & $-14.03^{\circ}, 296.27^{\circ}$ & -2386.05 & 146.20 & 68.38 & 7.59 & 6.76 \\
\hline SE Copr. & $\mathrm{C} 2$ & C2_D & $-14.1^{\circ}, 296.48^{\circ}$ & -2285.82 & 215.82 & 31.07 & 9 & 6.72 \\
\hline SE Copr. & $\mathrm{C} 2$ & C2_E & $-14.17^{\circ}, 296.64^{\circ}$ & -2063.17 & 0.00 & 40.31 & 8.81 & 6.65 \\
\hline SE Copr. & $\mathrm{C} 2$ & $\mathrm{C} 2 \_\mathrm{F}$ & $-13.9^{\circ}, 296.62^{\circ}$ & -2686.17 & 65.41 & 9.18 & 7.42 & 6.74 \\
\hline SE Copr. & $\mathrm{C} 2$ & C2_G & $-13.97^{\circ}, 296^{\circ}$ & -2443.68 & 315.86 & 34.11 & 7.68 & 6.85 \\
\hline SE Copr. & $\mathrm{C} 2$ & C2_I & $-13.85^{\circ}, 296.5^{\circ}$ & -2587.83 & 109.10 & 19.64 & 8.65 & 6.85 \\
\hline SE Copr. & $\mathrm{C} 2$ & $\mathrm{C} 2 \_\mathrm{J}$ & $-13.75^{\circ}, 296.37^{\circ}$ & -2334.81 & 210.70 & 62.72 & 7.78 & 7.19 \\
\hline SE Copr. & $\mathrm{C} 3$ & $\mathrm{C} 2 \_\mathrm{K}$ & $-13.78^{\circ}, 295.53^{\circ}$ & -2289.47 & 78.62 & 5.76 & 9.01 & 7.02 \\
\hline SE Copr. & $\mathrm{C} 3$ & $\mathrm{C} 2 \_\mathrm{L}$ & $-13.81^{\circ}, 296.64^{\circ}$ & -2289.48 & 78.53 & 5.88 & 7.73 & 6.67 \\
\hline SE Copr. & $\mathrm{C} 2$ & C2_M & $-13.77^{\circ}, 296.1^{\circ}$ & 2658.55 & 179.96 & 4.73 & 8.31 & 7.2 \\
\hline SE Copr. & $\mathrm{C} 2$ & $\mathrm{C} 2 \_\mathrm{N}$ & $-13.91^{\circ}, 296.68^{\circ}$ & -2567.51 & 315.86 & 8.23 & 7.36 & 6.91 \\
\hline SE Copr. & $\mathrm{C} 2$ & $\mathrm{C} 2 \_\mathrm{O}$ & $-14.12^{\circ}, 296.55^{\circ}$ & -2355.47 & 109.10 & 28.88 & 8.01 & 6.67 \\
\hline SE Copr. & $\mathrm{C} 2$ & $\mathrm{C} 2 \_\mathrm{P}$ & $-13.78^{\circ}, 296.24^{\circ}$ & 2638.11 & 210.70 & 6.09 & 8.82 & 7 \\
\hline SE Copr. & $\mathrm{C} 2$ & $\mathrm{C} 2 \_\mathrm{Q}$ & $-13.85^{\circ}, 296.78^{\circ}$ & -2243.34 & 137.53 & 12.04 & 6.74 & 6.77 \\
\hline SE Copr. & $\mathrm{C} 2$ & C2_R & $-13.89^{\circ}, 296.56^{\circ}$ & -2791.45 & - & 5.66 & 8.81 & - \\
\hline SE Copr. & $\mathrm{C} 3$ & C3_A & $-13.98^{\circ}, 296.13^{\circ}$ & -2550.64 & - & 0.76 & 7.32 & - \\
\hline SE Copr. & $\mathrm{C} 3$ & C3_B & $-13.98^{\circ}, 296.18^{\circ}$ & -2681.36 & - & 0.54 & 8.83 & - \\
\hline SE Copr. & $\mathrm{C} 3$ & C3_C & $-14.01^{\circ}, 296.28^{\circ}$ & -2685.19 & - & 1.05 & 4.67 & - \\
\hline SE Copr. & $\mathrm{C} 3$ & C3_D & $-13.98^{\circ}, 296.12^{\circ}$ & -2625.75 & - & 0.80 & 10.9 & - \\
\hline SE Copr. & $\mathrm{C} 3$ & C3_E & $-13.99^{\circ}, 296.16^{\circ}$ & -2467.27 & - & 0.62 & 10.51 & - \\
\hline SE Copr. & $\mathrm{C} 3$ & $\mathrm{C} 3 \_\mathrm{F}$ & $-14^{\circ}, 296.22^{\circ}$ & 2714.74 & - & 0.97 & & \\
\hline Juventae & $\mathrm{J} 1$ & J1_A & $-5.16^{\circ}, 298.68^{\circ}$ & -747.47 & - & 18.61 & 6.29 & - \\
\hline Juventae & $\mathrm{J} 1$ & J1_B & $-5.2^{\circ}, 298.56^{\circ}$ & -468.44 & - & 19.68 & 6.8 & - \\
\hline Juventae & $\mathrm{J} 1$ & $\mathrm{~J} 1 \_\mathrm{C}$ & $-5.1^{\circ}, 298.87^{\circ}$ & -1076.32 & - & 30.54 & 6.06 & - \\
\hline Juventae & $\mathrm{J} 2$ & J2_A & $-5.01^{\circ}, 298.75^{\circ}$ & -2341.29 & 211.08 & 76.63 & 4.84 & 5.18 \\
\hline Juventae & $\mathrm{J} 2$ & J2_B & $-5.02^{\circ}, 298.61^{\circ}$ & -2512.62 & 118.98 & 23.91 & 4.77 & 5.15 \\
\hline
\end{tabular}

*SE Copr. $=$ Southeast Coprates. $\sigma=$ Extracted from MOLA.

$\dagger=$ Where apex is not clear, most upslope location is given

Table S1: Morphometrics of alluvial fans in SE Coprates and Juventae Chasma. Fan naming convention: e.g., $\mathrm{C} 1=$ The first generation (oldest) of Coprates fans; $\mathrm{J} 2=$ The second generation (youngest) of Juventae fans. Numbers have been assigned with decreasing age: e.g., C1 is older than $\mathrm{C} 2$, which is older than $\mathrm{C} 3$. Each individual fan within a generation has also been assigned a letter: e.g., C2_E = Fan E within the second generation of Coprates fans. Catchment area and fan surface slope measurements were made using available CTX DEMs and the ArcGIS hydrology toolkit. Catchment measurement were only made where the catchment was well-preserved and clearly linked to the fan apex. This was only possible for the $\mathrm{C} 2$ and $\mathrm{J} 2$ generations of fans. For 
the $\mathrm{C} 1$ and $\mathrm{J} 1$ fans, the catchment has been overprinted. For the $\mathrm{C} 3$ fans, their small size meant their apices could not be fitted to the flow direction raster and attempts to reconstruct a hydrological catchment were unsuccessful.

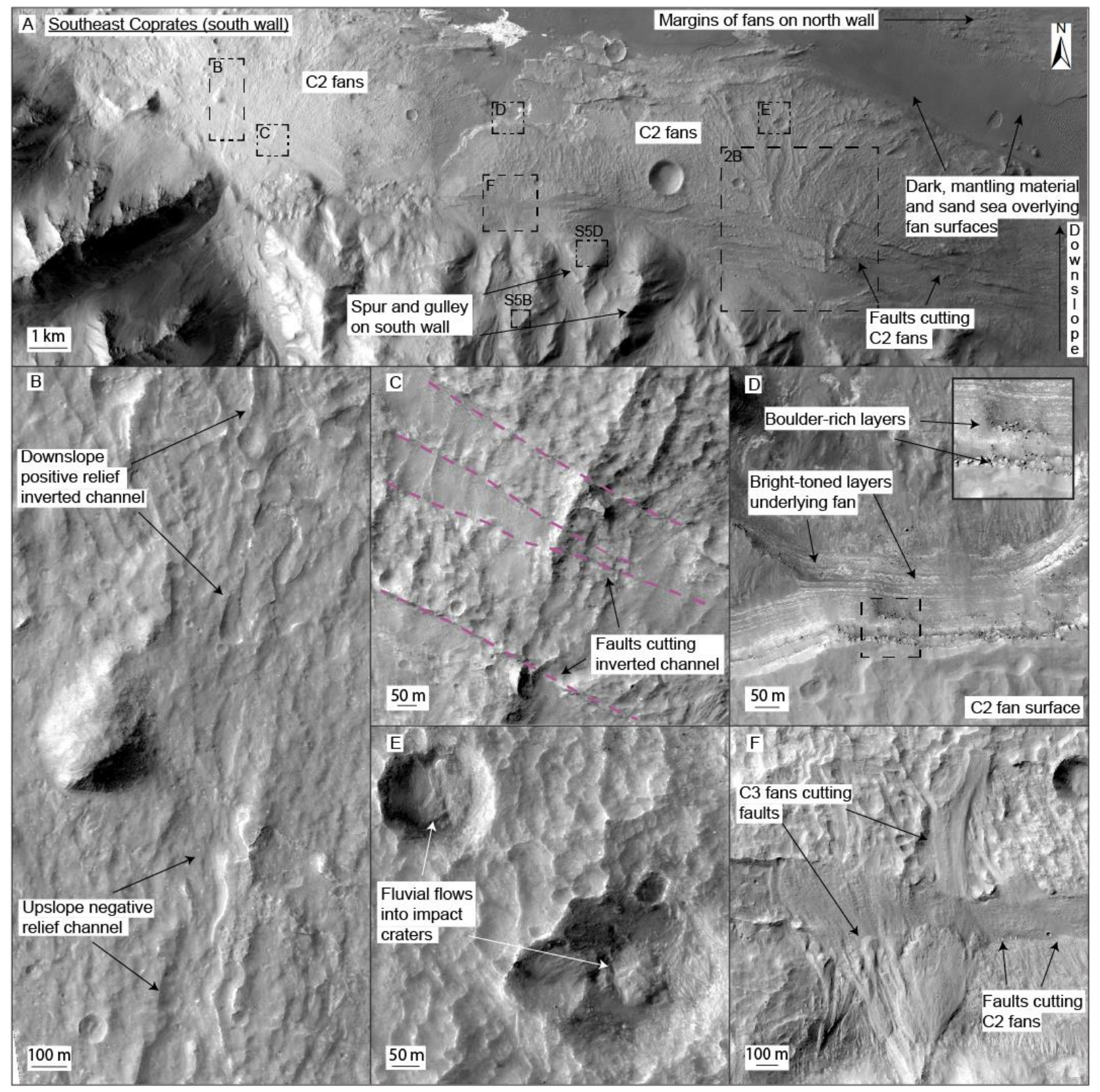

Figure S2: (A) CTX image mosaic of alluvial fan deposits and bajadas on southern wall of Southeast Coprates Chasma canyon. (B) HiRISE images of negative relief on C2 fan surface transitioning downslope into (positive relief) inverted channel, likely due to increased erosion. (C) HiRISE image of inverted channel on C2 fan surface which has been cut by multiple faults. (D) HiRISE image into backwasted margins of $\mathrm{C} 2$ alluvial fans, exposing sub-horizontal layering. Darker, boulder-rich layers overlie, bright-toned layers which may be associated with possible playas. (E) HiRISE image of embedded impact craters on C2 fan surfaces. These impact 
craters has formed in between episodes of sedimentation and have sequentially been infilled by later fluvial deposits. Their presence points to hiatuses between flow events. (F) HiRISE image of $\mathrm{C} 3$ alluvial fans, which cut across the faulted $\mathrm{C} 2$ fan surfaces.

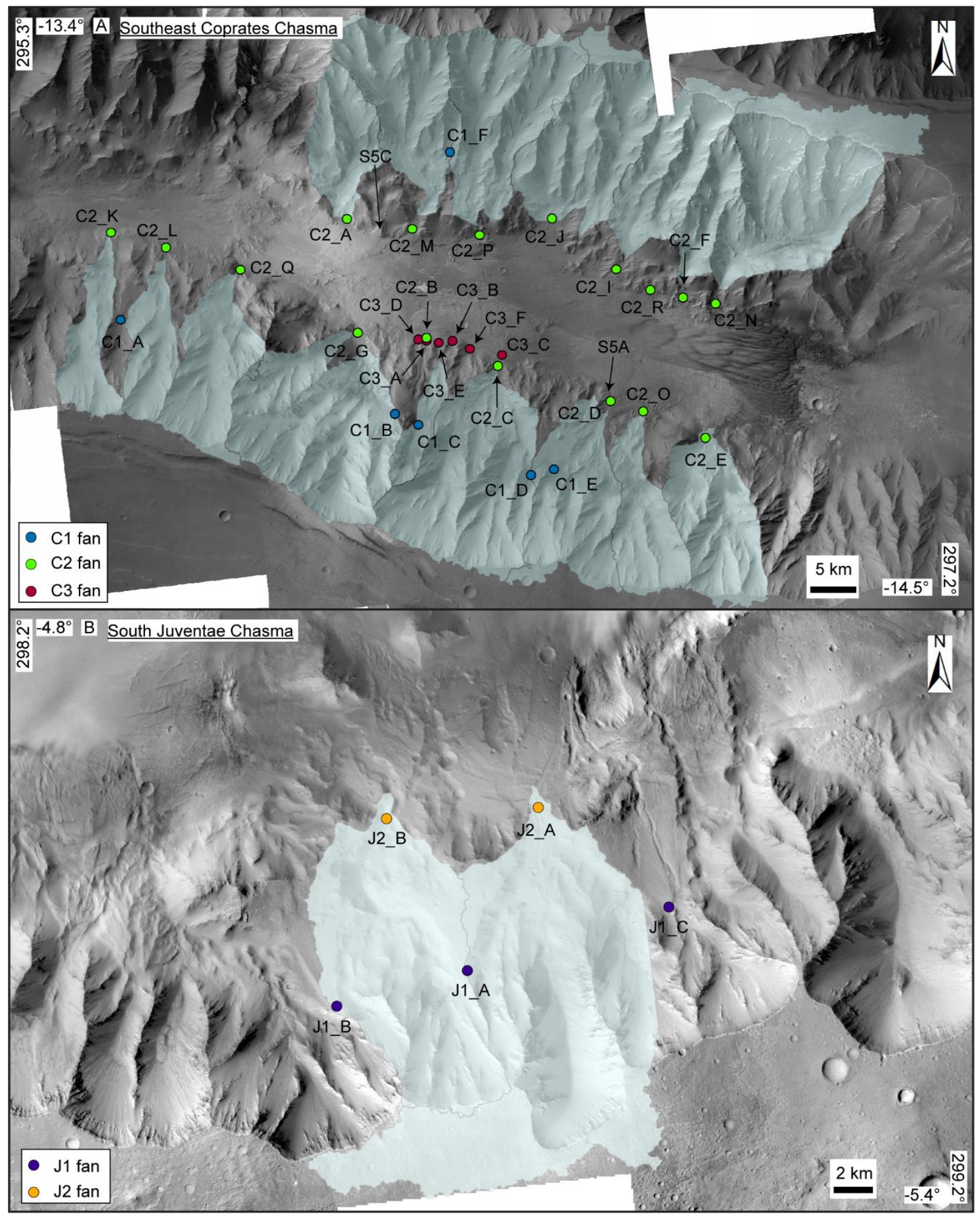


Figure S3: (A) CTX mosaic showing SE Coprates Chasma. The coloured circles show the apices for three generations of sediment fans $(\mathrm{C} 1, \mathrm{C} 2, \mathrm{C} 3)$. The shaded blue area shows the reconstructed catchment for the C2 fans. (A) CTX mosaic showing south Juventae Chasma. The coloured circles show the apices for two generations of sediment fans $(\mathrm{J} 1, \mathrm{~J} 2)$. The shaded blue area shows the reconstructed catchment for the $\mathrm{J} 2$ fans.
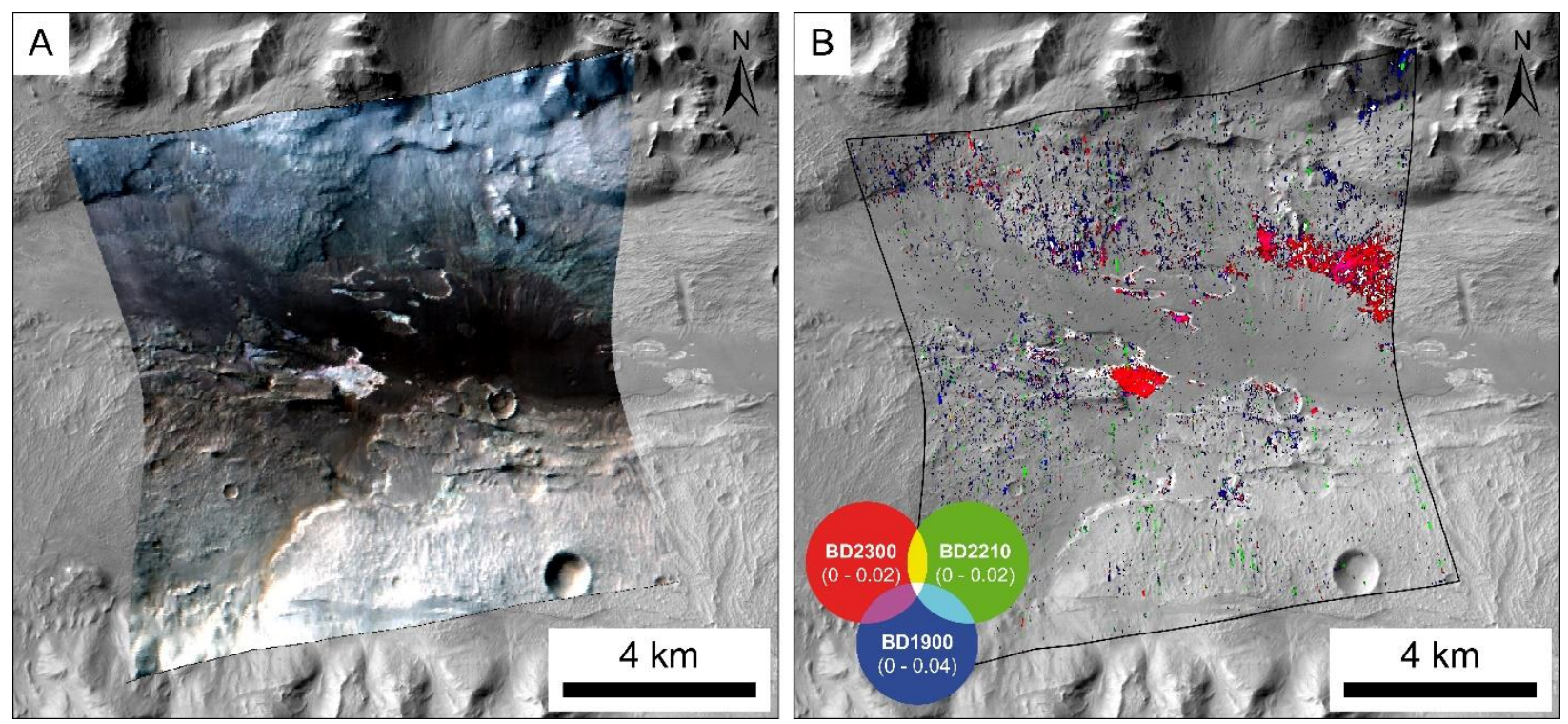

Figure S4: Likely presence of hydrous minerals in sedimentary material in SE Coprates Chasma. (A) CRISM false-colour image of canyon floor. Image FRT0000ABB7, processed using standard techniques (e.g. Murchie et al., 2007; 2009). (B) CRISM phyllosilicate spectral parameter map of the light-toned layered deposits in the center of the southeast Coprates Chasma basin. Spectral parameters derived using standard techniques (e.g. Viviano-Beck et al., 2014)). Red $=$ BD2300, green $=$ BD2210, blue $=$ BD1900. Hydroxylated and hydrated silicates, probably mostly $\mathrm{Fe} / \mathrm{Mg}$-rich (identified from 2.3 micron absorption feature), are confined to outcrops of light-toned material, or where darker material appears thinner, occurring at the lowest elevations and the distal end of depositional fan material. $\mathrm{BD}=$ band depth. Detections are similar to those which occur in the adjacent SE Coprates Catena to the east (Grindrod et al., 2012; 2018). 


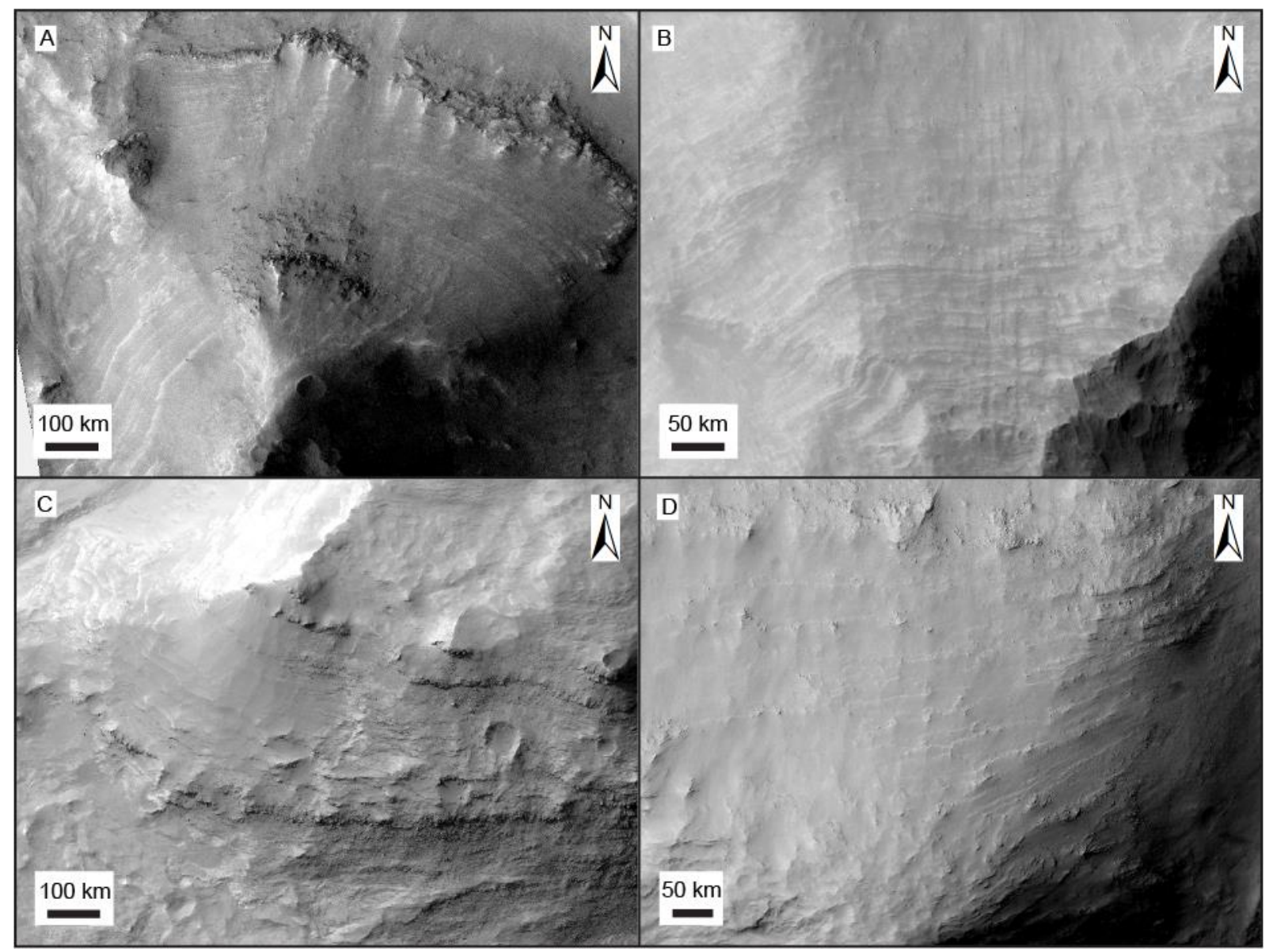

Figure S5: Examples of layered deposits visible in HiRISE images found in both the north and south wall of the SE Coprates Chasma study site. The layered deposits are found in the canyon wall between the $\mathrm{C} 1$ and $\mathrm{C} 2$ fan deposits (see Fig. 1). We interpret these layered deposits as sedimentary deposits, likely a combination degraded remnants of $\mathrm{C} 1$ sediment fans and the underlying sediment basement material. We note that the layered deposits are only visible in HiRISE images. There is currently no HiRISE coverage above the elevation of the $\mathrm{C} 1$ fans and CTX images suggests that the layered deposits do not occur here. See Fig. S2 and S3 for context locations. 


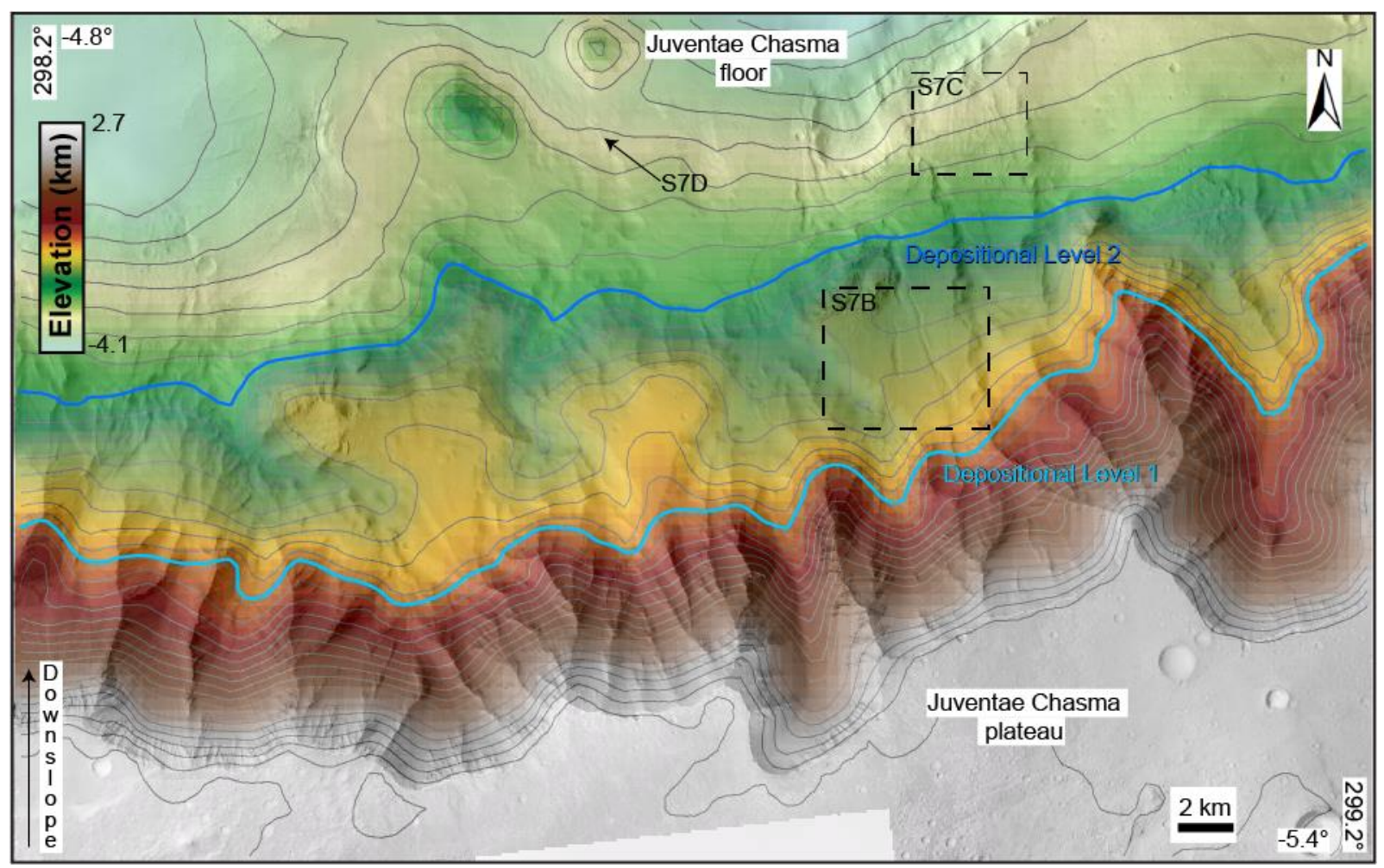

Figure S6: Stereo MOLA topographic map of Juventae Chasma study site, overlaid on CTX basemap mosaic showing vertically separated levels of sediment deposition clustered at $\sim-850 \mathrm{~m}$ and $\sim-2400 \mathrm{~m}$. 


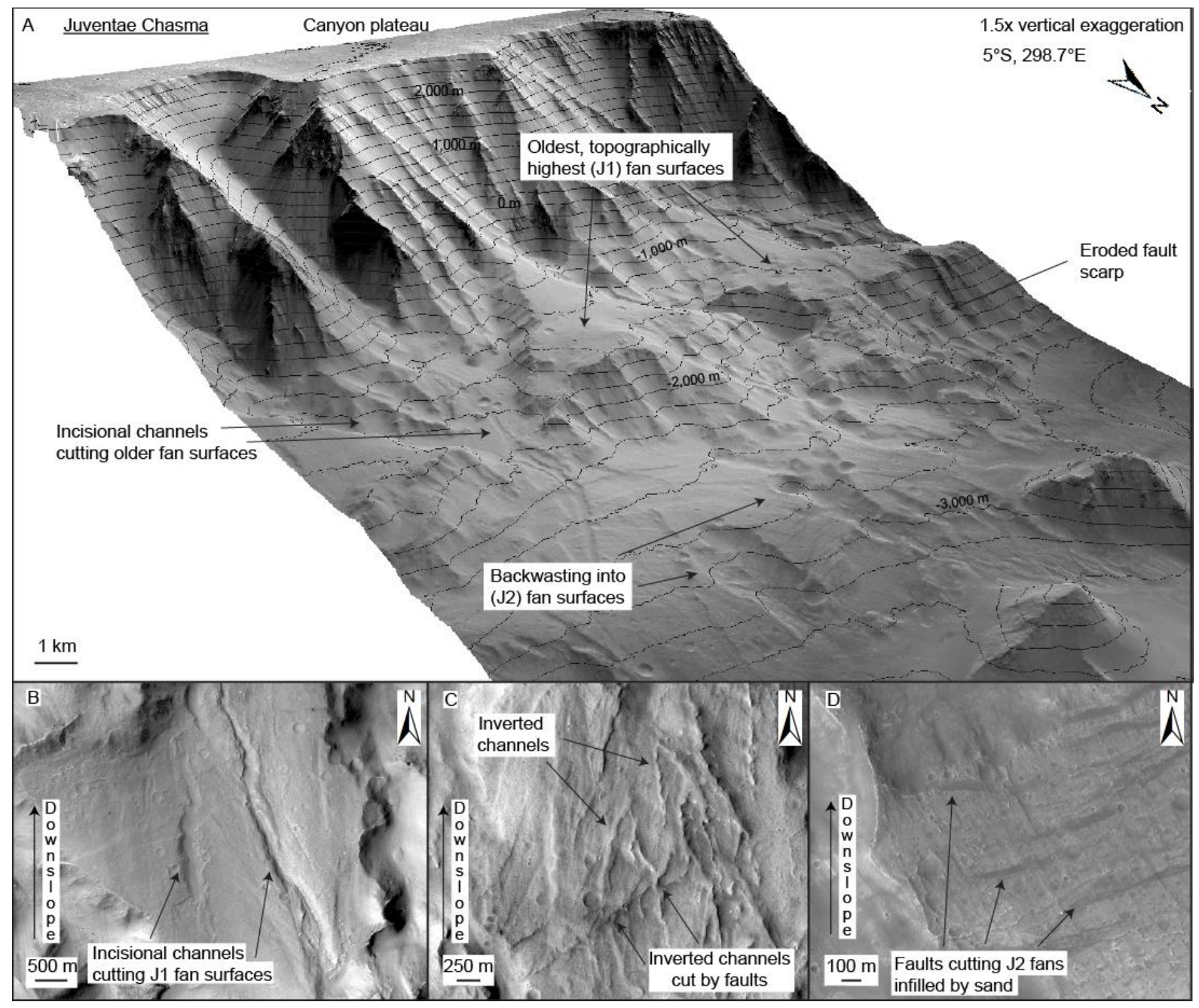

Figure S7: (A) Oblique CTX view of perched terraces, interpreted as faulted alluvial fan deposits, on the southern wall of Juventae Chasma. At least two generations (J1 \& J2) of alluvial fan deposits are visible, which are found at similar elevations along the canyon wall. Some remnant channels are visible on their surfaces. Like in Coprates Chasma, the oldest (J1) fan surfaces are over a kilometer from the canyon floor. The $\mathrm{J} 2$ fans have also been left relatively uplifted. A third generation of alluvial fan deposits may exist on the current canyon floor, although these are buried by an extensive sand sea. Contours are shown at $200 \mathrm{~m}$ intervals. The morphometrics of these fans are shown in Table S1. (B) CTX image showing incisional channels that cut through the $\mathrm{J} 2$ fans. (C) CTX showing faulted inverted channels on J2 fan surfaces. (D) HiRISE image showing faults on $\mathrm{J} 2$ fan surface which have become infilled with sand. 

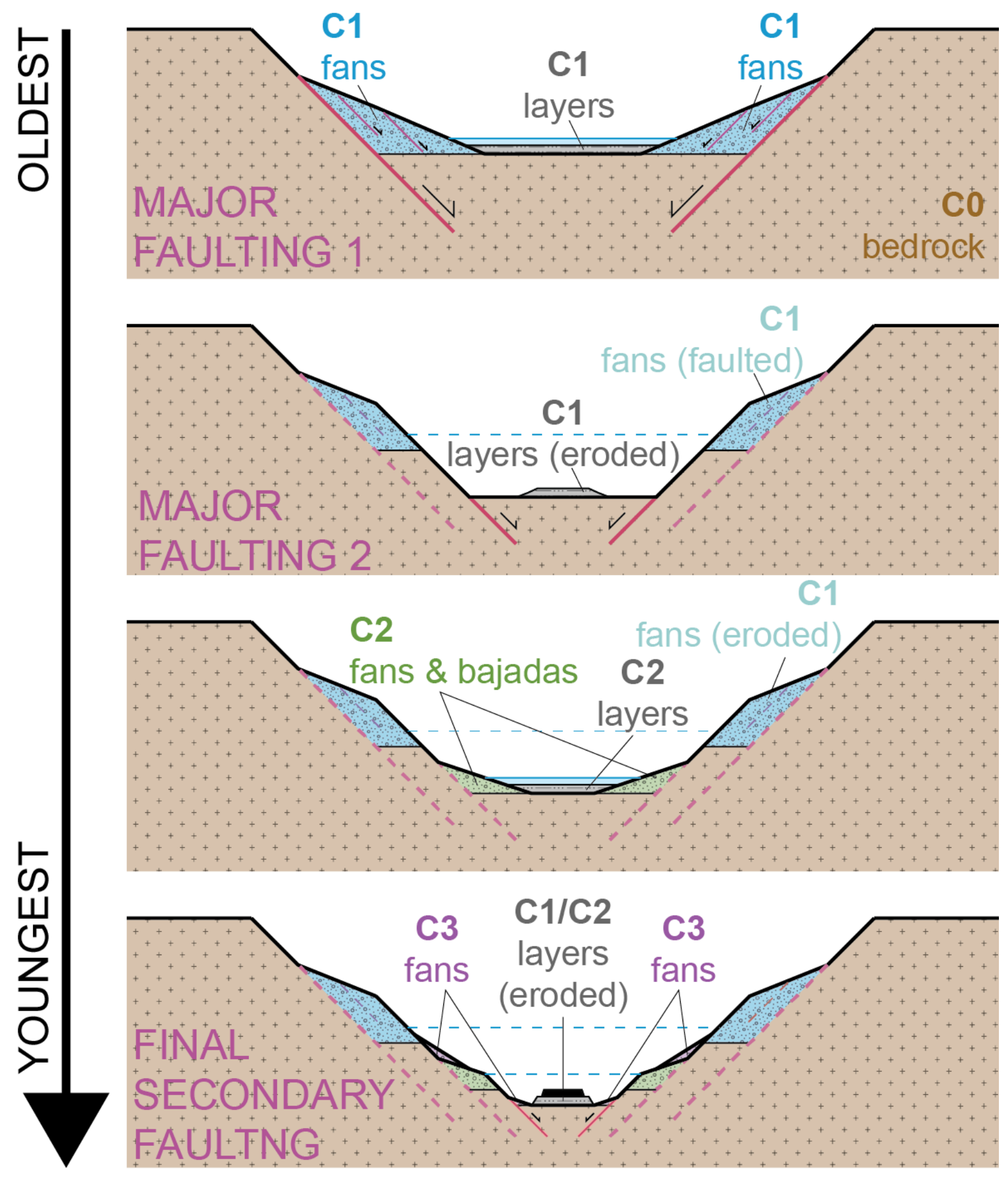

Figure S8: Simplified conceptual model showing multi-stage evolution of southeast Coprates Chasma. Successive generations of alluvial fans have formed as the canyon developed, assuming a progressive, basinward shift in normal faulting. Associated synthetic faults have cut the fan surfaces. Not to scale. 


\begin{tabular}{|c|c|c|}
\hline Figure & Instrument & Image ID \\
\hline \multirow{18}{*}{1} & CTX (DEM) & D21_035265_1668_XN_13S063W \\
\hline & & D21_035542_1668_XN_13S063W \\
\hline & & D18_034118_1660_XN_14S064W \\
\hline & & D21_035476_1672_XN_12S064W \\
\hline & & G04_019824_1673_XN_12S065W \\
\hline & & P07_003711_1680_XN_12S065W \\
\hline & & P08_004067_1681_XN_11S064W \\
\hline & & P12_005913_1642_XI_15S063W \\
\hline & & D19_034619_1672_XN__12S064W \\
\hline & & P06_003355_1673_XI_12S064W \\
\hline & & J01_045340_1658_XN_14S063W \\
\hline & & J11_048966_1660_XN_14S063W \\
\hline & & B02_010475_1667_XI_13S063W \\
\hline & & J01_045129_1667_XI_13S063W \\
\hline & & F02_036597_1674_XN_12S065W \\
\hline & & P14_006546_1670_XN_13S065W \\
\hline & & J05_046619_1666_XN_13S062W \\
\hline & & J09_048254_1668_XN_13S063W \\
\hline \multirow[t]{2}{*}{$2 \mathrm{a}$} & CTX (DEM) & B02_010475_1667_XI_13S063W \\
\hline & & J01_045129_1667_XI_13S063W \\
\hline \multirow[t]{2}{*}{$2 b$} & HiRISE & ESP_060465_1660 \\
\hline & & ESP_060465_1660 \\
\hline \multirow[t]{2}{*}{$2 c$} & CTX & B02_010475_1667_XI_13S063W \\
\hline & & J01_045129_1667_XI_13S063W \\
\hline \multirow[t]{2}{*}{3} & CTX & D10_030940_1752_XN__04S061W \\
\hline & & D09_030795_1752_XN_04S061W \\
\hline S1A & MOLA, THEMIS-IR Day & Global mosaic \\
\hline S1B & MOLA, THEMIS-IR Day & Global mosaic \\
\hline $\mathrm{S} 1 \mathrm{C}$ & MOLA, THEMIS-IR Day & Global mosaic \\
\hline \multirow[t]{2}{*}{ S2A } & CTX & J01_045129_1667_XI_13S063W \\
\hline & & P12_005913_1642_XI_15S063W \\
\hline S2B & HiRISE & ESP_061098_1660 \\
\hline S2C & HiRISE & ESP_061098_1660 \\
\hline S2D & HiRISE & PSP_008339_1660 \\
\hline $\mathrm{S} 2 \mathrm{E}$ & HiRISE & ESP_060043_1660 \\
\hline $\mathrm{S} 2 \mathrm{~F}$ & HiRISE & PSP_008339_1660 \\
\hline S3A & CTX & Same as Fig. 1 \\
\hline \multirow[t]{3}{*}{ S3B } & CTX & D10_030940_1752_XN_04S061W \\
\hline & & $\mathrm{J} 04046342 \quad 1770 \mathrm{XN} 03 \mathrm{~S} 061 \mathrm{~W}$ \\
\hline & & P15_007060_1770_XN_03S062W \\
\hline \multirow[t]{2}{*}{ S4 } & CRISM & FRT0000ABB7 \\
\hline & CTX & P12_005913_1642_XI_15S063W \\
\hline S5A & HiRISE & ESP_061098_1660 \\
\hline S5B & HiRISE & PSP_008339_1660 \\
\hline S5C & HiRISE & PSP_008339_1660 \\
\hline S5D & HiRISE & ESP_055625_1660 \\
\hline \multirow[t]{4}{*}{ S6 } & MOLA & Global mosaic \\
\hline & CTX & D10_030940_1752_XN_04S061W \\
\hline & & J04_046342_1770_XN_03S061W \\
\hline & & P15_007060_1770_XN_03S062W \\
\hline \multirow[t]{2}{*}{ S7A } & CTX (DEM) & D10_030940_1752_XN_04S061W \\
\hline & & $\mathrm{D} 090307951752 \times \mathrm{N} 04 \mathrm{~S} 061 \mathrm{~W}$ \\
\hline S7B & CTX & D10_030940_1752_XN_04S061W \\
\hline
\end{tabular}




$\begin{array}{lll}\text { S7C } & \text { CTX } & \text { B20_017424_1773_XN_02S061W } \\ \text { S7D } & \text { HiRISE } & \text { PSP_006203_1750 }\end{array}$

Table S2: List of instruments and image IDs used in figures.

\section{References}

Grindrod, P.M., Warner, N.H., Hobley, D.E.J., Schwartz, C., and Gupta, S., 2018, Stepped fans and facies-equivalent phyllosilicates in Coprates Catena, Mars: Icarus, v. 307, p. 260280, doi:10.1016/j.icarus.2017.10.030.

Grindrod, P.M., West, M., Warner, N.H., and Gupta, S., 2012, Formation of an Hesperian-aged sedimentary basin containing phyllosilicates in Coprates Catena, Mars: Icarus, v. 218, p. 178-195, doi:10.1016/j.icarus.2011.11.027.

Kirk, R.L., Howington-Kraus, E., Rosiek, M.R., Anderson, J.A., Archinal, B.A., Becker, K.J., et al. (2008). Ultrahigh resolution topographic mapping of Mars with MRO HiRISE stereo images: Meter-scale slopes of candidate Phoenix landing sites. Journal of Geophysical Research, 113, E00A24, https://doi.org/10.1029/2007JE003000.

Murchie, S., et al. (2007), Compact Reconnaissance Imaging Spectrometer for Mars (CRISM) on Mars Reconnaissance Orbiter (MRO), Journal of Geophysical Research, 112, E05S03, https://doi.org/10.1029/2006JE002682.

Murchie, S., et al. (2009), Evidence for the origin of layered deposits in Candor Chasma, Mars, from mineral composition and hydrologic modeling, Journal of Geophysical Research, 114, E00D05, https://doi.org/10.1029/2009JE003343.

Viviano- Beck, C. E., et al. (2014), Revised CRISM spectral parameters and summary products based on the currently detected mineral diversity on Mars, J. Geophys. Res. Planets, 119, 1403- 1431, doi:10.1002/2014JE004627.

Zuber, M.T., Smith, D.E., Solomon, S.C., Muhleman, D.O., Head, J.W., Garvin, J.B., et al. (1992). The Mars Observer laser altimeter investigation. Journal of Geophysical Research, 97, 7781-7797. https://doi.org/10.1029/92JE00341 